\title{
PERSONS AND OTHER THINGS
}

Exploring the Philosophy of the Hebrew Bible 


\section{Also by the Author}

The Raven, the Dove, and the Owl of Minerva: The Creation of Humankind in Athens and Jerusalem

"I AM": Monotheism and the Philosophy of the Bible 


\title{
Persons and Other Things
}

\author{
Exploring the Philosophy \\ of the Hebrew Bible
}

MARK GLOUBERMAN

UNIVERSITY OF TORONTO PRESS

Toronto Buffalo London 
(C) University of Toronto Press 2021

Toronto Buffalo London

utorontopress.com

Printed in the U.S.A.

ISBN 978-1-4875-0898-2 (cloth)

ISBN 978-1-4875-3945-o (EPUB)

ISBN 978-1-4875-3944-3 (PDF)

\section{Library and Archives Canada Cataloguing in Publication}

Title: Persons and other things : exploring the philosophy of the

Hebrew Bible / Mark Glouberman.

Names: Glouberman, M., author.

Description: Includes bibliographical references and index.

Identifiers: Canadiana (print) 20210145757 | Canadiana (ebook) 20210145781 |

ISBN 9781487508982 (cloth) | ISBN 9781487539450 (EPUB) |

ISBN 9781487539443 (PDF)

Subjects: LCSH: Bible. Old Testament - Philosophy. |

LCSH: Jewish philosophy.

Classification: LCC BS1186 .G66 2021 | DDC 221.601 - dc23

This book has been published with the help of a grant from the Federation for the Humanities and Social Sciences, through the Awards to Scholarly

Publications Program, using funds provided by the Social Sciences and

Humanities Research Council of Canada.

University of Toronto Press acknowledges the financial assistance to its publishing program of the Canada Council for the Arts and the Ontario Arts Council, an agency of the Government of Ontario. 
If the concept of God has any validity or any use, it can only be to make us larger, freer, and more loving.

James Baldwin, Letter from a Region in My Mind 
This page intentionally left blank 